\title{
Buddhist entrepreneurs, charitable behaviors, and social entrepreneurship: evidence from China
}

\author{
Zuhui Xu $\cdot$ Zhiyang Liu $\cdot$ Jie Wu
}

Accepted: 5 October 2021 / Published online: 24 December 2021

(C) The Author(s) 2021

\begin{abstract}
To address the lacuna of how informal institutions like Buddhism impact social entrepreneurship in different regions within a nation, this research draws on the social entrepreneurship literature and the regional Buddhist research to propose a mediating framework where the percentage of Buddhist entrepreneurs in a region is positively associated both with the level of prosocial behaviors such as charity, due to the values of Buddhism, and with the probability of establishing businesses in a lessdeveloped region. It further proposes that charitable behaviors mediate the relationship between the percentage of Buddhist entrepreneurs in a region and establishing businesses in less-developed regions.
\end{abstract}

Supplementary Information The online version contains supplementary material available at https://doi. org/10.1007/s11187-021-00570-w.

Z. Xu

School of Business Administration, Nanjing University

of Finance and Economics, No.3, Wenyuan Road,

Nanjing 210023, China

e-mail: xuzuhui1990@163.com

Z. Xu

China Research Center for Social Entrepreneurship,

Shanghai University of Finance and Economics, No.288,

Wudong Road, Shanghai 200433, China

Z. Liu $(\square)$

College of Business, Shanghai University of Finance and Economics, No.777, Guoding Road, Shanghai 200433,
This mediating effect is attributed to the mechanism that charitable behaviors absorb the limited resources of entrepreneurs, reducing their resources for establishing businesses in less-developed regions. We test these hypotheses on nationwide surveys of founders of private enterprises and find support for this mediating view. Broad implications for theoretical and empirical research are discussed.

Plain English Summary This study distinguishes between the different influences of Buddhist entrepreneurs in a region both on charitable behaviors and on the establishment of businesses in less-developed regions. Using nationwide surveys of founders of private enterprises in the Chinese context, multilevel analyses support a mediating view and have several implications. This research proposes that Buddhist

China

e-mail: zhiyang163@163.com

Z. Liu

China Research Center for Social Entrepreneurship, Shanghai University of Finance and Economics, No.288, Wudong Road, Shanghai 200433, China

J. Wu ( $\square)$

University of Aberdeen Business School, King's College, University of Aberdeen, Aberdeen AB24 3FX, UK e-mail: jie.wu@abdn.ac.uk 
values like the Four Immeasurables underline the positive effect of Buddhist entrepreneurs in a region on charitable behaviors, and that Buddhism can bring the essence of entrepreneurship, such as social capital, political connections, and legitimacy, to entrepreneurs and stimulate them, through an isomorphic effect, to engage in establishing businesses in lessdeveloped regions. Furthermore, we highlight that the influence of Buddhist entrepreneurs in a region on establishing businesses in less-developed regions is weakened when they commit limited resources to prosocial behaviors like charity. In relation to policy, our study shows that Buddhist values and practices deeply influence social entrepreneurship, and it highlights the social function of Buddhist entrepreneurs in a transitional economy such as that of China.

Keywords Buddhism - Informal institution - Social entrepreneurship · Prosocial behaviors · China

\section{JEL classifications $\quad \mathrm{B} 52 \cdot \mathrm{L} 26 \cdot \mathrm{L} 31 \cdot \mathrm{M} 14 \cdot \mathrm{Z} 12$. O53}

\section{Introduction}

Social entrepreneurship is regarded as a means of addressing a wide range of social problems, such as poverty and discrimination (Dacin et al., 2011; Short et al., 2009; Wu \& Si, 2018; Wu et al., 2022). There has been increasing effort in the social entrepreneurship field to explore the important role of institutions in social entrepreneurial behaviors and outcomes. This stream resonates well with institutional theory as a framework to explain the relationship between the institutional environment and social entrepreneurial activities and outcomes (North, 1991, 2005; Scott, 2005; Su et al., 2017).

A number of institutions have been investigated in this stream of research, alongside the state and market logics of formal institutions. Specifically, market logic includes business friendliness (Hörisch et al., 2017), market inclusivity (Ault, 2016), and marketsupporting institutions (Zhao \& Lounsbury, 2016), while state logic covers constraints on executives (Estrin et al., 2013), government activism (Estrin et al., 2013; Nissan et al., 2012; Stephan et al., 2015), governmental support (Hörisch et al., 2017), local authorities (Muñoz \& Kibler, 2016), and regulatory quality (Hoogendoorn, 2016). Informal institutions include environmental pressure (Hörisch et al., 2017), in-group collectivism (Pathak \& Muralidharan, 2016), post-materialism (Hörisch et al., 2017; Stephan et al., 2015), religion (Tracey, 2012; Zhao \& Lounsbury, 2016), socially supportive cultural norms (Stephan et al., 2015), traditional and self-expression societal values (Hechavarría, 2016; Hoogendoorn, 2016), and trust (Nissan et al., 2012; Pathak \& Muralidharan, 2016).

However, very few efforts have been devoted to examining the effects of religion on social entrepreneurial behaviors and outcomes. This lacuna is surprising, because the values and social norms of religion, as an informal institution, deeply influence entrepreneurial activities and outcomes from the perspective of institutional theory (North, 1991, 2005; Scott, 2005; Su et al., 2017). These entrepreneurial activities and outcomes include entrepreneurial motivation (Audretsch et al., 2013; Parboteeah et al., 2015), new venture creation (Dodd \& Seaman, 1998), entrepreneurial risk-taking (Hilary \& Hui, 2009; Neubert et al., 2017), and entrepreneurial performance (Ibrahim \& Angelidis, 2005; Liu et al., 2019). Some studies (Tracey, 2012; Zhao \& Lounsbury, 2016) have begun to explore the relationship between religion and social entrepreneurship; for example, Zhao and Lounsbury (2016) studied how religious diversity affects resource acquisition by microfinancing organizations, finding that the religious diversity of a country is negatively associated with the amount of commercial capital therein. This line of research has largely focused on Western religions, and it has tended to neglect the fact that social entrepreneurship may face different institutional pressures in different regions within a nation, such as in those regions with many Buddhist entrepreneurs. Moreover, compared with Western religions, Buddhism preaches very different and important values like the Four Immeasurables (Kriger \& Seng, 2005; Marques, 2012; Pace, 2013).

To address this lacuna, the present study draws on the social entrepreneurship literature and regional Buddhist research to shed light on the relationship between the percentage of Buddhist entrepreneurs in a region and social entrepreneurship. Specifically, it proposes that the percentage of Buddhist entrepreneurs in a region is positively associated with the level of prosocial behaviors such as charity, due to the values of Buddhism. The percentage of Buddhist 
entrepreneurs in a region is positively associated with the probability of establishing businesses in less-developed region. We also propose that charitable behaviors mediate the relationship between the percentage of Buddhist entrepreneurs and the establishment of businesses in less-developed regions, and that this is because charitable behaviors absorb limited resources possessed by entrepreneurs, reducing their resources for establishing businesses in less-developed regions. We test these hypotheses on nationwide surveys of founders of private enterprises. Results from multilevel analyses support a mediating view and have broad implications for theoretical and empirical research on institutions, social entrepreneurship, and poverty reduction.

This study makes two important theoretical contributions to research on institutions and entrepreneurship. First, it adds to current research on the antecedents of social entrepreneurship by focusing on the influence of the percentage of Buddhist entrepreneurs in a region on social entrepreneurship. Drawing on social influence literature (e.g., Brock \& Durlauf, 2001; Topa, 2001), we argue that the percentage of Buddhist entrepreneurs in a region can affect social entrepreneurship in two important ways. On the one hand, the high percentage of Buddhist entrepreneurs in a region influences other entrepreneurs' behaviors through the isomorphic effect. On the other hand, non-Buddhist entrepreneurs have to adopt similar prosocial behaviors as they interact with the large percentage of Buddhist entrepreneurs in a region who share common values and norms that generate a pervasive Buddhist atmosphere for employees, customers, and suppliers. For example, Buddhist values like the Four Immeasurables can trigger entrepreneurs' charitable behaviors; essential features of entrepreneurship like social capital, political connections, and legitimacy underlie the effect of entrepreneurs on establishing businesses in less-developed regions.

Second, this study contributes to the literature on prosocial activities by conceptualizing charitable behaviors and the establishment of businesses as two distinct activities. The former activity is relatively passive, and the latter is relatively proactive (Bolino \& Grant, 2016), because establishing businesses involves proactive activities such as integrating local abundant resources, which is never part of charitable behaviors (Austin et al., 2006; Dees, 1998). At the same time, charitable behaviors are oriented toward the short term, whereas the establishment of businesses has a long-term orientation. This is because the latter involves identifying and capturing entrepreneurial opportunities, which are persistent and tend to a long-term orientation; charitable behaviors, however, involve the entrepreneur directly donating resources such as money and goods to povertystricken areas, which may be disposable and tend to have a short-term orientation (Wang \& Qian, 2011; Yiu et al., 2014). Moreover, we go beyond the existing prosocial activities literature to investigate the relationship between the two types of prosocial activities. We propose that passive charitable behaviors mediate the relationship between the percentage of Buddhist entrepreneurs in a region and the establishment of businesses in less-developed regions. At a theoretical level, we highlight the tradeoff of resource allocation between charitable behaviors and the establishment of businesses in less-developed regions. Our findings offer a novel perspective for demonstrating how certain types of prosocial behaviors, such as charity, substantially absorb entrepreneurs' limited resources, thereby reducing their resources for establishing businesses in less-developed regions.

\section{Chinese institutions and social entrepreneurship}

Institutions are built on certain deep aspects of the social structure, which can guide and constrain individual behavior (North, 1991, 2005; Scott, 2005). In formal institutions, government actions create both objective constraints and incentives for individual and organizational behaviors (Scott, 1995, 2005; Su et al., 2017). Formal institutions are primarily driven by two different logics: state logic and market logic. State logic focuses on the role of government, such as government activism, the legal system, and individual perceptions of government support, while market logic emphasizes market-based transactions, such as a business-friendly environment and market-supporting institutions (Su et al., 2017). Informal institutions include cognitive and normative aspects. The cognitive aspect refers to cultural values that people understand, while the normative aspect refers to existing social practices in the related culture (Scott, 2005; Stephan et al., 2015; Su et al., 2017).

As the world's largest transitional economy, China has a unique institutional environment (Liu et al., 
2019; Su et al., 2017). Formal institutions (e.g., government activism and law enforcement) are weak or incomplete in various regions of China, whereas informal institutions, including religion and culture, may play an alternative role in economic and social development (Su et al., 2017; Williamson, 2000). China has a long religious history: Buddhism spread into China about 2,000 years ago (Ling, 2004). Chinese Buddhism has combined with indigenous Confucian ethics, such as the obligations of humaneness and altruism. Buddhist activities were largely reduced during the period of the Cultural Revolution, because the key values of Buddhism ran counter to the atheist doctrine of the Chinese Communist Party. Since 1978, China has undertaken a process of reform and opening up, part of which has been the realization that people have more diversified religious demands. Indeed, the Chinese are deeply influenced by Buddhism, and Buddhism has become the largest religion in China, exceeding Taoism, Protestantism, Catholicism, Islam, and so on (Yang, 1961). The number of Buddhists is estimated to be in the range of 185 million (Jin \& Qiu, 2011) to 300 million (Lim, 2010) people.

The extant social entrepreneurship literature has considered the influence of formal institutions on social entrepreneurship as primarily being based on state and market logics; however, the understanding of how other institutional logics, such as religion, influence the social entrepreneurial process remains limited (Su et al., 2017; Urbano et al., 2019). Furthermore, there are two conflicting perspectives on the influence of formal institutions on social entrepreneurship: the institutional void perspective and the institutional support perspective. These perspectives present the relationship between formal institutions and social entrepreneurship in markedly different ways. According to the institutional void perspective, a less active government can bring about greater social problems, thus leading to an increased demand for social entrepreneurship to solve these problems (Estrin et al., 2013; Zahra et al., 2009). From the institutional support perspective, however, a more active government can provide key tangible and intangible resources for social entrepreneurship, thereby supporting and enhancing such entrepreneurship (Korosec \& Berman, 2006; Zahra \& Wright, 2011). More importantly, social entrepreneurship is jointly constrained or motivated by formal and informal institutions based on the perspective of institutional configurations (Stephan et al., 2015).

According to a 2006 national survey of founders of private enterprises, about $12 \%$ of entrepreneurs had participated in entrepreneurial opportunitycapturing behaviors, such as establishing businesses in less-developed regions with the aim not only of capturing uncertain entrepreneurial opportunities but also of developing new agricultural products to enhance local employment and reduce poverty (Yiu et al., 2014). For example, some entrepreneurs found abundant resources for Chinese medicine in the lessdeveloped regions of China, such as in rural areas, and established new ventures to produce technologically advanced traditional Chinese medicine, such as Tibetan medicines. Other entrepreneurs produced and sold konjac (an edible plant similar to the potato) by sharing their advanced technology and distribution networks with local farmers (Yiu et al., 2014).

Building on the existing social entrepreneurship literature (Wu et al., 2020; Zahra et al., 2009), the present study contends that social entrepreneurship in emerging markets should take account of two key aspects. On the one hand, social entrepreneurship aims to maximize the values of commercial and social welfare simultaneously, rather than maximizing only the value of commercial welfare (Austin et al., 2006). On the other hand, social entrepreneurship addresses social goals and missions by implementing critical entrepreneurial behaviors, such as identifying and capturing entrepreneurial opportunities (Dees, 1998). To develop this insight, we conceptualize social entrepreneurship as consisting of two independent but closely related behaviors: charitable behaviors and entrepreneurial opportunity-capturing behaviors. While prosocial behaviors are non-commercial actions that promote or protect the welfare of individuals, groups, or organizations, and include organizational citizenship behavior, mentoring, knowledge sharing, and charity (Bolino \& Grant, 2016), entrepreneurial opportunity-capturing behaviors characteristically establish businesses in less-developed regions not only to capture uncertain and novel entrepreneurial opportunities but also to enhance local employment and reduce poverty (Brief \& Motowidlo, 1986; Wu \& Si, 2018; Wu et al., 2020). Such a conceptualization extends the existing concept of social entrepreneurship by explicitly distinguishing between 
two related but independent components that have largely been treated indistinctly in previous studies.

\section{Theory development and hypotheses}

Buddhist entrepreneurs are entrepreneurs who have embraced Buddhist beliefs in a way that affects their attitude toward social and commercial behaviors. This definition has two important implications. The first is that Buddhist entrepreneurs are different from non-Buddhist entrepreneurs. Non-Buddhist or normal entrepreneurs are motivated to discover and exploit appropriate business opportunities for profit and competitive advantage, and thus focus primarily on economic returns (Austin et al., 2006; Wu et al., 2016). They are overwhelmingly concerned with discovering and exploiting novel but inherently uncertain profitable opportunities (Venkataraman, 1997). In contrast, Buddhist entrepreneurs are motivated not only by business opportunities and profitability, but also by their Buddhist beliefs. Buddhism preaches a fundamental doctrine of karma, which encourages its believers (including Buddhist entrepreneurs) to focus on the benefits of the community rather than those of his or her own self, because bad acts generate bad karma as depicted in The Diamond Sutra (Pace, 2013). The second important Buddhist value is impermanence, which reminds its believers that there is no everlasting happiness, so it is important for an individual to take advantage of what they presently possess in the world to work for the benefit of the community (Marques, 2012). Critically, mercy is the most important elemental force behind the Four Immeasurables (i.e., compassion, loving kindness, empathetic joy, and equanimity), ${ }^{1}$ because it constantly stimulates its believers to undertake effective

\footnotetext{
${ }^{1}$ Compassion, which is a core value of social entrepreneurship, involves one person feeling the negative feelings and suffering of another person, and experiencing the same states as if they were their own personal emotions. Loving kindness pertains to taking care of others and pursuing altruistic acts, supporting the important approach of social entrepreneurship. There is a complementary relationship between compassion and loving kindness, with loving kindness focusing on positive feelings, and compassion addressing the negative sufferings. Sympathetic joy is the ability to find, express, and appreciate this joy with others, which strengthens social entrepreneurship. Equanimity means that one should not try to gain a superior status to that of others, implying that entrepreneurs should pay attention to the interests of stakeholders, such as employees,
}

means to benefit society rather than just the individual. These means, which are so-called prosocial activities, can be either passive (e.g., donations, charities) or proactive (e.g., setting up a business to create more job opportunities for a poor community) (Bolino \& Grant, 2016). It is this doctrine of mercy that stimulates Buddhists to engage in prosocial means.

The second implication is that Buddhist entrepreneurs are motivated to undertake proactive means that are different from the passive means adopted by pure Buddhists. This can be illustrated by the difference between Buddhist entrepreneurs and Buddhist monks, who are the typical type of pure Buddhist. Monks perform their daily activities by closely following the Four Immeasurables (i.e., compassion, loving kindness, empathetic joy, and equanimity), with the purpose of fighting against the temptations of the flesh and gaining an eternal life in otherworldliness. As such, they adopt a passive attitude toward worldly activities. They consciously break up their social connections with the present world and escape from worldly activities into temples or mountains, with the result that their lives as cloistered monks are greatly limited. Although monks are encouraged by the doctrine of mercy to participate in prosocial activities, their prosocial means take a passive form (e.g., donations of their own personal belongings). In contrast, Buddhist entrepreneurs cannot escape from worldly activities; rather, they have to engage in business activities as part of the responsibility of entrepreneurship (Jiang et al., 2015; Liu et al., 2019). They are motivated by the doctrine of mercy to undertake passive prosocial means such as donation and charity, but they are also driven by an inner entrepreneurial spirit to go beyond passive prosocial means and consider proactive business means. Some Buddhist entrepreneurs even treat business activities as an effective way of embarking on their religious pilgrimage to the eternal life. For example, establishing a new business in a less-developed region generates more job opportunities for the region's poor people and thus provides more sustainable help for the poor areas (Wu \& Si, 2018). Thus, establishing businesses in

Footnote 1 (continued) customers, suppliers, and so on. In this respect, equanimity underpins the thinking behind social entrepreneurship (Kriger and Seng 2005; Marques 2012; Pace 2013). 
less-developed regions is a proactive means of helping poor people, which shows them the mercy of the Buddha (Du et al., 2016; Yiu et al., 2014). In other words, Buddhist entrepreneurs not only undertake passive prosocial means just as pure Buddhists do, but they also undertake proactive prosocial means of establishing new businesses in less-developed regions to help local people who are struggling with poverty.

As the number of Buddhists entrepreneurs increases in a region, it has a decisive influence on prosocial activities in two important ways. First, a large number of Buddhists (including Buddhist entrepreneurs) in a region certainly cultivates Buddhism's core value and norms (e.g., karma, impermanence, the Four Immeasurables). The values and norms gradually attract more local people to Buddhism. Such a local Buddhist group consists of a large number of loyal believers who convert to the religion, and they tend to share the common beliefs and adopt common attitudes and behaviors toward each other and those out-group people with whom they interact (Brock \& Durlauf, 2001; Topa, 2001).

Second, as the local Buddhist group expands further to cover a much broader range of people, it naturally forms its social norms and regulations that guide its members' activities and conduct toward society (Scott, 2005; Su et al., 2017). Good deeds, like donations and charitable acts, become more common in those regions that have an increasing number of Buddhist believers. In addition, a large number of Buddhists in a region encourages more proactive prosocial activities through the isomorphic effect. This isomorphic effect occurs via three mechanisms. First, when a large number of Buddhist entrepreneurs choose to establish businesses in less-developed regions, pressure is exerted on other entrepreneurs who have not chosen to establish businesses but heavily depend on those entrepreneurs who have done so. They may feel pressure to join these Buddhist entrepreneurs in undertaking the same proactive means to meet social expectations (DiMaggio \& Powell, 1983; Marquis et al., 2007). Second, in an emerging market, like that of China, where there is a lack of developed institutional infrastructure and transparent information, uncertainty is a powerful force that encourages imitation among entrepreneurs (Wu et al., 2020). When Buddhist entrepreneurs increasingly capture the fundamental benefit of political connections at the regional level by establishing businesses in less-developed regions, they become exposed to key information embedded in social networks and interactions with local officers and authority (Greenberg, 2000; Portes \& Sensenbrenner, 1993). Other entrepreneurs observe and imitate these entrepreneurs' behaviors in order to reduce competitive and market uncertainty (Bai et al., 2021; DiMaggio \& Powell, 1983). Third, as more and more Buddhist entrepreneurs establish businesses in less-developed regions, it creates a cognitive base for a pool of entrepreneurs who possess similar social positions and make similar business investments for exchanging information, resources, and knowledge (DiMaggio \& Powell, 1983). To access the legitimacy among these entrepreneurs, other entrepreneurs are encouraged to conform to this normative isomorphism by devoting their resources to less-developed regions (Brock \& Durlauf, 2001; Topa, 2001; see Appendix 1 for the detailed review).

\subsection{Buddhist entrepreneurs and charitable behaviors}

We argue that the percentage of Buddhist entrepreneurs in a region has a positive effect on prosocial behaviors such as charity for two reasons. First, as discussed above, the existence of a large number of Buddhists in a region can trigger a common attitude toward the world and cultivate a shared cognition, which provide the basis for social interactions that induce an irresistible tendency to conformity in behaviors (Brock \& Durlauf, 2001; Topa, 2001). This logic also applies to the percentage of Buddhist entrepreneurs in a region in relation to their prosocial behaviors like charity. The more Buddhist entrepreneurs that are in a region, the more likely it is that they socially interact with Buddhist-related stakeholders, such as employees, customers, and suppliers. As a result of this interaction, Buddhist values (e.g., the Four Immeasurables) are reinforced and enlarged, which in turn motivates the Buddhist entrepreneurs to adopt prosocial behaviors such as charity (Pace, 2013). Compassion (karuna), which refers to the sympathetic feelings toward others who are in a bad situation, and leads the Buddhist entrepreneurs to enact prosocial behaviors, such as charitable donations (Wang \& Qian, 2011; Weaver \& Agle, 2002), with the aim of helping those others to overcome their difficulties. Moreover, loving kindness (metta) can be achieved by engaging in charitable acts that 
are beneficial to others (Pace, 2013). Sympathetic joy (mudita) motivates Buddhist entrepreneurs to find joy in helping others, and such joy involves participating in unselfish behavior, such as charitable acts. Equanimity (upekkha) guides local entrepreneurs not to seek a status superior to that of others, but rather to pay attention to the interests of stakeholders, such as employees, customers, and suppliers (Marques, 2012), through prosocial activities such as charitable behaviors. In short, the core values of Buddhism encourage the Buddhist entrepreneurs to care about their social goals and missions by participating in charitable behaviors, rather than only being concerned with economic value (Angelidis \& Ibrahim, 2004; Valliere, 2008).

Second, a large number of Buddhist entrepreneurs in a region influence non-Buddhist entrepreneurs' prosocial behaviors through the isomorphic effect. The norms and practices embraced by a large number of Buddhist entrepreneurs at the regional level generate a coercive power that forces non-Buddhist entrepreneurs to adopt similar modes in their social interactions. Moreover, in a region with more Buddhist entrepreneurs, these Buddhist entrepreneurs implement their religious practices by establishing Buddhist organizations (Henley, 2017; Liu et al., 2019). Such organizations may be informal, such as charitable foundations that strive to preach the Four Immeasurables, and this creates a social norm that guides their charitable behaviors (Brock \& Durlauf, 2001; Topa, 2001). Other entrepreneurs who are influenced by such norms are more willing to devote themselves to benefiting other people and guiding them toward charitable behaviors (Du et al., 2016; Parboteeah et al., 2015). Thus, we hypothesize the following:

Hypothesis 1: The percentage of Buddhist entrepreneurs in a region is positively related to the level of charitable behaviors.

\subsection{Buddhist entrepreneurs and entrepreneurial opportunity-capturing behaviors}

Buddhist entrepreneurs are expected to go beyond charitable behaviors to engage in a relatively proactive means such as establishing businesses in lessdeveloped regions, due to both the "own-effects" of Buddhist entrepreneurs themselves and social influences of Buddhist entrepreneurs in a region. On the one hand, for the "own-effects" of Buddhist entrepreneurs themselves, the Buddhist doctrine motives Buddhist entrepreneurs to establish businesses in lessdeveloped regions as a way to achieve their religious fulfillment (Marques, 2012; Pace, 2013). Specifically, in encountering a situation where poor people in lessdevelop regions are suffering many difficulties and miseries, an entrepreneur who embraces the compassion naturally shows strong sympathy toward negative emotions and feelings. She or he is then motivated to undertake some certain business activities in order to help these poor people. Meanwhile, loving kindness, the second component of the Four Immeasurables, entails altruistic behavior such as capturing uncertain entrepreneurial opportunities in less-developed regions. Furthermore, sympathetic joy makes Buddhist entrepreneurs more sympathetic toward those in need, driving them to participate in establishing more businesses in less-developed regions. In addition, equanimity helps to enhance Buddhist entrepreneurs' sense of moral obligation for participating in establishing businesses in less-developed regions. The "own-effects" of Buddhist entrepreneurs themselves derived from the Four Immeasurables and together from unique identity of entrepreneur naturally motivate them to engage in establishing businesses in lessdeveloped regions to satisfy cognitive needs and normative commands from the religious belief and career aspiration.

On the other hand, social influences of Buddhist entrepreneurs in a region also have impacts on the likelihood of other entrepreneurs' participation in establishing businesses in less-developed regions. We identify three types of social influences-social capital, political connections, and legitimacy — which are couched within the isomorphic effect (Wu et al., 2016). First, a large number of Buddhist entrepreneurs in a region may exert the pressure of social expectations on other entrepreneurs if the former consistently establish businesses in less-developed regions. Shared religious beliefs greatly facilitate social interactions and cooperation among entrepreneurs, which is fundamental for building social capital (Greenberg, 2000; Portes \& Sensenbrenner, 1993). Although Buddhism does not have weekly ceremonies and rituals, Buddhist entrepreneurs have greater motivation to assist other entrepreneurs who hold the same beliefs. Buddhist entrepreneurs are typically more easily available through affiliation 
with particular Buddhist groups, such as a Buddhist foundation or a Zen foundation. Moreover, reciprocity and enforceable trust are two mechanisms that operate between Buddhist entrepreneurs and their co-Buddhist partners in business activities (Portes $\&$ Sensenbrenner, 1993). Where there is a high percentage of Buddhist entrepreneurs in a region, other entrepreneurs are more likely to heavily depend on these Buddhist entrepreneurs (Brock \& Durlauf, 2001; Topa, 2001), especially in relation to guanxi or social connections in the context of Chinese Confucianism (Tsui \& Farh, 1997). The community of Buddhist entrepreneurs at the regional level exerts pressure on other entrepreneurs and forces them to undertake the same proactive means to meet social expectations, such as establishing businesses in lessdeveloped regions (DiMaggio \& Powell, 1983; Marquis et al., 2007).

Second, the percentage of Buddhist entrepreneurs in a region makes other entrepreneurs imitate the same behaviors if the establishment of businesses in less-developed regions reduces competitive and market uncertainty. Buddhist entrepreneurs can achieve an extremely broad representation in the Chinese political system, because they cater to religious believers, business people, and the private sector ( $\mathrm{Du}$, 2017). Chinese entrepreneurs with Buddhist beliefs can acquire political connections by, for example, becoming involved in organizations like the People's Congress (PC) and/or the Chinese People's Political Consultative Committee (CPPCC) (Liu et al., 2019). These political connections can help the Buddhist entrepreneurs build close relationships with government authorities, which in turn can reduce competitive and market uncertainty. Government officials are often experts on national policies and guidelines, such as those in relation to poverty alleviation and development (Wu \& Si, 2018). These policies and guidelines help Buddhist entrepreneurs acquire key information and establish businesses in less-developed regions (Liu et al., 2019; Zhao \& Lu, 2016). An emerging market like China has a weak institutional environment and high uncertainty, which encourages imitation among entrepreneurs ( $\mathrm{Wu}$ et al., 2020). This capturing of political connections by Buddhist entrepreneurs in a region not only serves as a model for interactions with local officers and authority ( $\mathrm{Du}$, 2017; Liu et al., 2019), which should push more Buddhist entrepreneurs to engage in establishing businesses in less-developed regions, but it also leads other entrepreneurs to reduce their uncertainty and fear by imitating and observing these Buddhist entrepreneurs' behaviors (Bai et al., 2021; DiMaggio \& Powell, 1983).

Third, the percentage of Buddhist entrepreneurs in a region encourages other entrepreneurs to conform to the requirements of establishing businesses in lessdeveloped regions so that they can access the legitimacy. The percentage of Buddhist entrepreneurs in a region creates a cognitive base for a pool of entrepreneurs who establish businesses in less-developed regions, which leads to other entrepreneurs conforming to this normative isomorphism in order to gain legitimacy (Brock \& Durlauf, 2001; Topa, 2001). For one thing, Buddhism guides Buddhist entrepreneurs to undertake proactive prosocial behaviors rather than to focus only on economic returns, such as by establishing new businesses in less-developed regions to help local people who are struggling with poverty (Pace, 2013). Where there are a high percentage of Buddhist entrepreneurs in a region, other entrepreneurs are more likely to socially interact with Buddhist entrepreneurs who possess similar social positions and make similar business investments in less-developed regions. The establishment of businesses in less-developed regions helps other entrepreneurs to obtain legitimacy among these Buddhist entrepreneurs. In addition, Buddhism encourages Buddhist entrepreneurs to take a long-term orientation toward business behaviors (Marques, 2012). A long-term orientation entails Buddhist entrepreneurs treating stakeholders more carefully (Brigham et al., 2014; Kriger \& Seng, 2005; Valliere, 2008); for example, establishing new businesses in less-developed regions generates more job opportunities for local poor people and thus provides more sustainable help for poor areas (Wu \& Si, 2018). In regions with high levels of Buddhist entrepreneurs, other entrepreneurs are more likely to be influenced by Buddhist entrepreneurs and take a long-term orientation toward business behaviors. Such a long-term orientation also helps other entrepreneurs gain legitimacy with stakeholders (Brigham et al., 2014; Shane \& Cable, 2002). For example, Buddhist entrepreneurs and village cadres exchange formal and informal capital information like bank loans, information from marketing channels about bringing new agricultural products to new markets, and large resource commitments necessary 
for establishing businesses in less-developed regions (Yiu et al., 2014).

In summary, more Buddhist entrepreneurs in these regions cultivates a sort of social interaction (Brock \& Durlauf, 2001; Topa, 2001) and even generates a pervasive Buddhist atmosphere that forces other entrepreneurs to adopt an isomorphic behaviors such as establishing businesses in less-developed regions. We therefore hypothesize the following:

Hypothesis 2: The percentage of Buddhist entrepreneurs in a region is positively related to the probability of establishing businesses in less-developed regions.

\subsection{The mediating role of charitable behaviors}

As explained above, this study draws on the social entrepreneurship literature to conceptualize charities and establishing businesses in less-developed regions as two distinct prosocial activities (Austin et al., 2006; Dees, 1998). It does so in two important ways. First, charities are closer to passive prosocial behaviors, whereas establishing businesses in lessdeveloped regions is closer to proactive prosocial behaviors (Bolino \& Grant, 2016), because the latter involves many proactive activities, such as integrating local abundant resources, which are never part of charitable behaviors (Austin et al., 2006; Dees, 1998). Second, charities are oriented more toward the short term, whereas establishing businesses in less-developed regions has a more long-term orientation. The latter involves identifying and capturing entrepreneurial opportunities that are persistent and more likely to generate a long-term orientation toward business behaviors, whereas charitable behaviors involve the entrepreneur directly donating disposable resources, such as money and goods, to poverty-stricken areas, which is more likely to lead to a short-term orientation toward business behavior (Wang \& Qian, 2011; Yiu et al., 2014).

No prior studies have suggested that entrepreneurs' establishing businesses in less-developed regions are more likely to predict their charitable behaviors; moreover, the prior literature has indicated that charitable behaviors can help entrepreneurs gain legitimacy and capture entrepreneurial opportunities, such as establishing businesses in less-developed regions (Liu et al., 2019; Wang \& Qian, 2011). Given this, we further argue that the effect of the percentage of
Buddhists in a region on proactive prosocial activities such as establishing businesses in less-developed regions is mediated by the passive role of charitable behaviors. Social capital, political connections, and legitimacy captured by Buddhist entrepreneurs in a region can provide certain key resources and information for establishing businesses in less-developed regions (Du, 2017; Greenberg, 2000; Stephan et al., 2015). However, charitable behaviors also result in the entrepreneur allocating a lot of resources to poverty-stricken areas (Du, 2015; Wang \& Qian, 2011). Entrepreneurs often have limited resources-which is especially the case in an emerging economy such as China, which has different levels of government control and decision-making about key resources (e.g., capital) — so their charitable behaviors substantially absorb these limited resources, thereby reducing their resources for establishing businesses in lessdeveloped regions. As such, the effect of Buddhist entrepreneurs in a region on establishing businesses in less-developed regions is weakened when other entrepreneurs commit limited resources to prosocial behaviors like charity. For this reason, we propose a partially mediating role of other entrepreneurs' charitable behaviors in the relationship between the percentage of Buddhist entrepreneurs in a region and the establishment of businesses in less-developed regions. Thus, we propose the following:

Hypothesis 3: Charitable behaviors mediate the positive relationship between the percentage of Buddhist entrepreneurs in a region and the probability of establishing businesses in less-developed regions.

\section{Data and methods}

\subsection{Data and sample}

The data were drawn from independent and representative sources, with individual-level and firm-level variables taken from nationwide surveys of founders of private enterprises, and province-level variables from the Marketization Index and China Statistics Yearbook (Fan et al., 2011; Yiu et al., 2014). The national survey provided independent, representative, and reliable information, because it was conducted by authoritative departments, such as the United Front Work Department of the Central Committee of the Communist Party of China, the All-China Federation 
of Industry and Commerce, the State Administration for Industry and Commerce of the People's Republic of China, and the China Society of Private Economy at the Chinese Academy of Social Sciences. The same data have been used in other social entrepreneurship studies, such as that by Yiu et al. (2014). The survey used a multistage stratified random sampling method by the All Provinces, Cities and Autonomous Regions Federation of Industry and Commerce.

Our final sample comprised 3,486 entrepreneurs from 31 provinces, for which full information on individual-level, firm-level, and province-level variables was available. The number of entrepreneurs per province ranged from 10 to 425 . Appendix 2 lists the provinces included in our study and provides province-level summary statistics. In terms of the regional development stage, the distributions in our sample are the eastern, central, and western regions.

\subsection{Variables and measures}

\subsubsection{Dependent variables}

The prior literature indicates that there are various organizational forms of social entrepreneurship in China, such as rural cooperatives, rural enterprises, and for-profit entrepreneurs who address social problems like poverty (Bhatt et al., 2019). We have drawn on some concepts about social entrepreneurship, such as those of Zahra et al. (2009), according to whom social entrepreneurship includes two aspects. The first aspect indicates that entrepreneurs establish businesses for the sake of capturing uncertain entrepreneurial opportunities; for example, some entrepreneurs establish businesses in less-developed regions by recognizing and capturing entrepreneurial opportunities. The second aspect suggests that entrepreneurs establish businesses to enhance local employment and reduce poverty; for example, new businesses in less-developed regions might develop new agricultural products in innovative ways.

Following previous literature, such as Yiu et al. (2014), this study has used two primary indicators to measure the dependent variable of establishing businesses in less-developed regions. These indicators reflect entrepreneurs' engagement in these entrepreneurial activities in order to reduce poverty, and they are consistent with the 2009 Global Entrepreneurship Monitor (GEM) survey's definition that social entrepreneurship includes using profits for socially oriented purposes (Lepoutre et al., 2013). For example, entrepreneurs establish businesses in less-developed regions not only to capture uncertain entrepreneurial opportunities but also to develop new agricultural products that help to alleviate poverty and improve local employment rates.

Entrepreneurs' engagement in entrepreneurial opportunity-capturing activities 1 (EO1) is a dummy variable for testing the main hypothesis. It takes a value of 1 if the entrepreneur has participated in establishing businesses in less-developed regions with the aim not only of capturing uncertain entrepreneurial opportunities but also of developing new agricultural products to enhance local employment and reduce poverty, and 0 otherwise. Following Yiu et al.'s (2014) definition, entrepreneurs' engagement in entrepreneurial opportunity-capturing activities 2 (EO2) is also a dummy variable used for our robustness test.

\subsubsection{Independent variables}

Following Hechavarría's (2016) finding that values appear to change rather very slowly, the independent variable of Buddhism denotes the percentage of Buddhist entrepreneurs in a region and is measured according to the average proportion of Buddhist entrepreneurs in various provinces of China from national surveys of founders of private enterprises (Liu et al., 2019; Zhao \& Lu, 2016). The national surveys were independently conducted by authoritative departments similar to those who reported for the 2006 nationwide survey, but for different years (2008 and 2010). The stability of the percentage of Buddhist entrepreneurs in a region between two waves of nationwide surveys is confirmed by a strong positive correlation between them $(r=0.806, p<0.01$, $N=31$ ). The Buddhist entrepreneur is a dummy variable that equals 1 if the entrepreneur of a private enterprise considers him/herself to be a Buddhist, and 0 otherwise.

\subsubsection{Mediating variables}

In line with past research on prosocial behaviors (Bolino \& Grant, 2016; Brief \& Motowidlo, 1986), this construct is reflected by the behavioral indicator of amount of charitable donations, since a greater 
amount of charitable donations can promote or protect the welfare of greater numbers of individuals, groups, or organizations (Bolino \& Grant, 2016; Twenge et al., 2007). This construct is indicated by the natural logarithm of the amount of an entrepreneur's charitable donations.

\subsubsection{Control variables}

Several individual-level, firm-level, and provincelevel variables were controlled in this study. The individual-level variables are gender, age, education, unemployment experience, rural poverty experience, startup location hardship, perceived institutional support, and political connections. Gender is a dummy variable, equaling 1 if the entrepreneur of the private enterprise is male, and 0 if female. Age is indicated by 2006 minus the year in which the entrepreneur was born. Human capital (HC) is a dummy variable, equaling 1 if an entrepreneur's educational level is at least junior (3-year) college, and 0 otherwise. Unemployment experience (UE) is a dummy variable that equals 1 if the entrepreneur of a private enterprise has experienced unemployment, and 0 otherwise. Rural poverty experience (RPE) is a dummy variable equaling 1 if the entrepreneur of a private enterprise has had prior experience of working on a village committee, and 0 otherwise. Startup location hardship (SLH) is a dummy variable equaling 1 if the private enterprise startup is located in a small city, town, or village, and 0 otherwise. Perceived institutional support (PIS) indicates the extent to which entrepreneurs perceive support from the legal document "36 Articles on Non-Public Economy." Perceived institutional support is an ordinal variable that uses a four-point Likert scale ranging from 1 ("strongly disagree") to 4 ("strongly agree"). Political connections (PC) is a dummy variable from a 2006 nationwide survey of founders of private enterprises that equals 1 if the entrepreneur is a deputy of the PC and/or the CPPCC, and 0 otherwise (Zhao \& Lu, 2016).

Firm-level variables comprise firm age and firm size. Firm age was measured by the natural logarithm of 2006 minus the year in which the firm registered as a private enterprise. Firm size was measured as the natural logarithm of the number of employees the firm had at its establishment. Province-level variables mainly refer to Gross Domestic Product (GDP) growth, law enforcement, government activism, and
Confucianism. To measure regional wealth, we used the 2006 GDP index compared to 2005-henceforth, referred to as GDP growth-from the 2006 China Statistics Yearbook. Law enforcement (LE) was measured according to the development of intermediary agencies and legal enforcement taken from Fan et al.'s (2011) Marketization Index. Government activism (GA) was measured as total government welfare expenditure on areas including health, education, and pensions as a percentage of GDP for every province (Stephan et al., 2015), taken from the 2006 China Statistics Yearbook. Confucianism is a dummy variable: provinces were coded 1 if they have nationally famous Confucian temples, and 0 otherwise. Appendix 3 summarizes the definitions of the variables.

\subsection{Model specification}

This study tested the theoretical model shown in Appendix 4 by using a multilevel design in which entrepreneurs (individual level) were nested within different regions of a country (regional level) (Peterson et al., 2012). To account for the non-independence and limit of entrepreneurs engaging in social entrepreneurship provided by the same provinces, we used logistic multilevel regression models (Wooldridge, 2010). Furthermore, we followed Baron and Kenny (1986) to test the mediating effect of prosocial behaviors, such as charity, on the relationship between Buddhist entrepreneurs in a region and the establishment of businesses in less-developed regions.

The procedure was as follows. First, we tested the positive relationship between Buddhist entrepreneurs in a region and establishing businesses in less-developed regions (Model 2, H2). Second, we examined the positive relationship between charitable behaviors and establishing businesses in less-developed regions (Model 3, no hypothesis). Third, we tested the positive relationship between Buddhist entrepreneurs in a region and prosocial behaviors, such as charity (Model 4, H1). Finally, we examined the influence of Buddhist entrepreneurs in a region on establishing businesses in less-developed regions after accounting for prosocial behaviors like charity (Model 5, H3). We used the Sobel test to examine the significance of the mediating role of prosocial behaviors, such as charity.

$\mathrm{EO}_{\mathrm{ij}}$ is our measure of entrepreneurial opportunity-capturing activities, used in Models 1, 2, 3, and 
5 for entrepreneurs. $\mathrm{CB}_{\mathrm{ij}}$ is our measure of charitable behaviors, used in Model 4 for entrepreneurs. All our models have a similar structure. In Eq. 1, the entrepreneur's charitable behaviors or engagement in establishing businesses in less-developed regions is a function of the province group intercept $\left(\beta_{0 j}\right)$ and a linear component of individual-level control variables (e.g., gender, age, human capital, unemployment experience) plus some random error $\left(r_{\mathrm{ij}}\right)$. Equation 2 specifies the group intercept $\left(\beta_{0 \mathrm{j}}\right)$ as a function of a common intercept $\left(\gamma_{00}\right)$ and a linear component made up of the province-level average of all individual-level control variables (e.g., GDP growth, law enforcement, government activism) plus a random, province-level error term $\left(u_{0 \mathrm{j}}\right)$ (see Appendix 5 for the detailed models).

\section{Results}

Table 1 displays the descriptive statistics and correlations for the individual-level and province-level variables. In Table 1, the mean of Buddhism is 0.165 , which is consistent with the Annual Report on Religions in China according to which Buddhism accounted for about $14.7 \%$ of the Chinese population (Jin \& Qiu, 2011). This indicates that the percentage of Buddhist entrepreneurs is a stable condition in China. Table 2 indicates the multicollinearity test for province-level variables. Analysis of the variance inflation factors (VIF) confirms that there are no serious multicollinearity issues, as the VIF scores are all lower than 10.

The models used to test the hypotheses are displayed in Table 3, which shows results regarding the mediating role of prosocial behaviors like charity between the percentages of Buddhist entrepreneurs in a region and establishing businesses in less-developed regions. In Table 3, Model 1 includes individual-level (Level 1) and province-level (Level 2) control variables. Model 2 adds the main effect of one focal predictor, and it shows both a positive effect of the level of Buddhist entrepreneurs in a region on entrepreneurs' engagement in establishing businesses in less-developed regions (Model 2: $\beta=1.024$, $p<0.01$ ) and a positive value of the marginal effect computed at the mean value of all variables between the two $(\beta=0.056, p<0.01)$, thereby supporting $\mathrm{H} 2$. In Model 3, the coefficient of prosocial behaviors like charity is positive and statistically significant (Model 3: $\beta=0.114, p<0.01)$. This result is consistent with the findings of prior studies regarding the relationship between charitable behaviors and establishing businesses in less-developed regions. Model 4 shows that the coefficient of the level of Buddhist entrepreneurs in a region is positive and statistically significant (Model 4: $\beta=3.187, p<0.05$ ), thus supporting H1. Model 5 tested H3, which pertains to the effect of the level of Buddhist entrepreneurs in a region on establishing businesses in less-developed regions when prosocial behaviors like charity is included. The coefficient of the level of Buddhist entrepreneurs in a region remains statistically significant $(p<0.01)$, but the magnitude level $(\beta=0.045, p<0.01)$ is lower than that of Model 2. The Sobel tests also confirmed the significance of the mediating effect of prosocial behaviors like charity $(\mathrm{Z}$ charitable behaviors $=2.419$, $p<0.01)$. Prosocial behaviors like charity mediated approximately $32.71 \%$ of the total effect of the level of Buddhist entrepreneurs in a region on establishing businesses in less-developed regions in Model 5. Overall, $\mathrm{H} 3$ is supported.

We also conducted multiple robustness checks. First, given that there are several different definitions of social entrepreneurship (Yiu et al., 2014), this study used EO2 as an alternative dependent variable. The results shown in Table 4 are very similar to those outlined in Table 3, which support H1, H2, and H3.

Second, this study also addressed endogeneity concerns. The results might have been driven by an unspecified omitted variable. Following studies such as that of Hilary and Hui (2009), this research added industry dummies, other cultural and personal variables (such as human capital, unemployment experience, rural poverty experience, startup location hardship, and Confucianism), and institutional voids (such as law enforcement and government activism) to empirical models to ensure that the percentage of Buddhist entrepreneurs in a region does not pick up the impact of these originally omitted variables.

It is also possible that the positive relationship between the percentage of Buddhist entrepreneurs in a region and establishing businesses in less-developed regions was driven by a reverse causality or by a latent variable. This study adopted an instrumental variable (IV) probit maximum likelihood estimator to solve this issue, following studies such as Jiang et al. (2015). In 1983, the State Council of China 


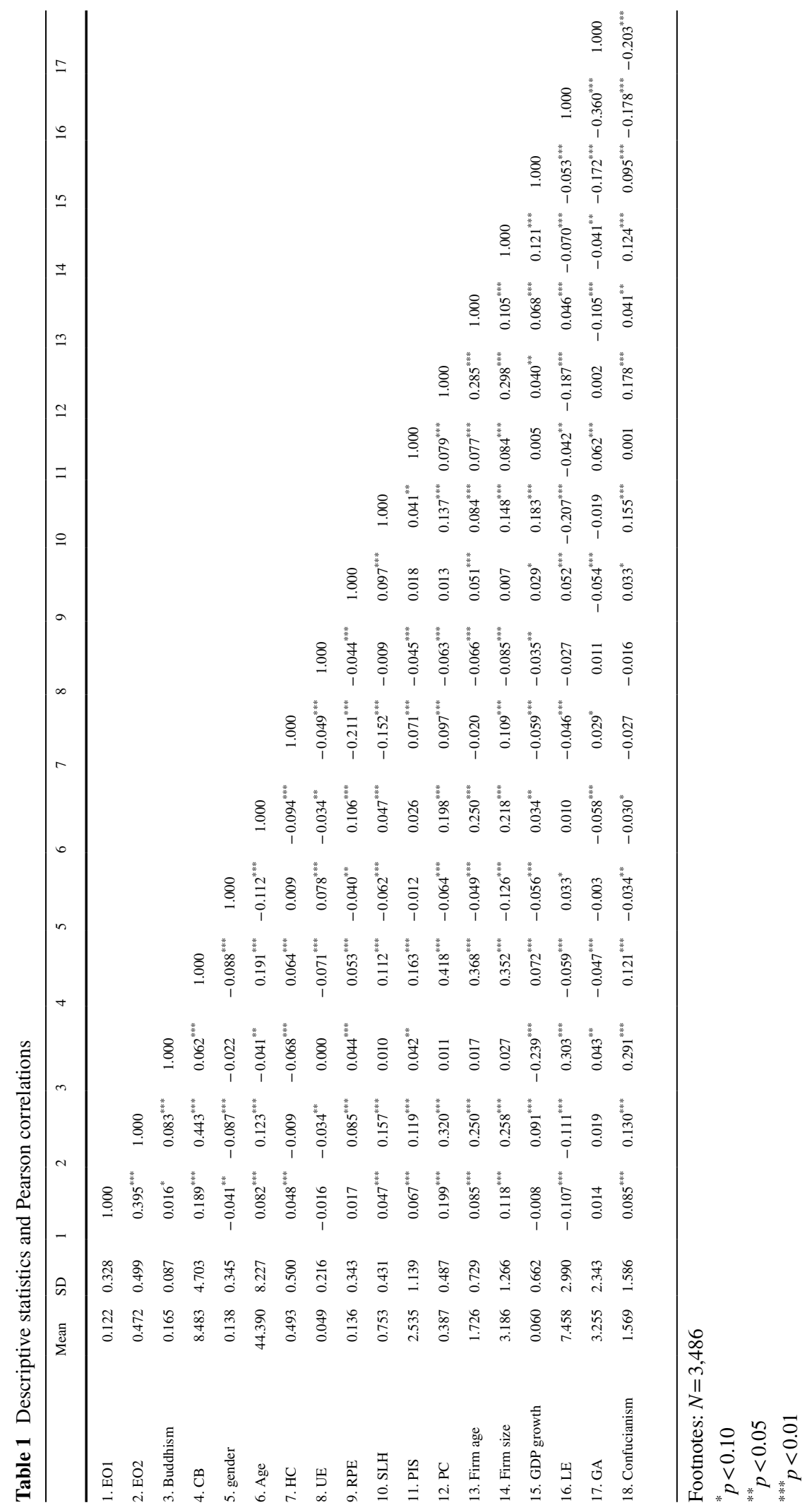


designated 142 temples as key temples for preservation. This study used Buddhist temples as an instrumental variable, which was measured by the number of key Buddhist temples per 10,000 people in a province. The number of Buddhist temples in a province may influence an entrepreneur's Buddhist beliefs, but it may be less relevant to establishing businesses in less-developed regions (Iannaccone, 1998; Jiang et al., 2015; Wooldridge, 2010). Following previous literature (Semadeni et al., 2014), we used Stock and Yogo's (2005) test and Cragg and Donald's (1993) F test to examine the validity of this instrumental variable, which indicated that the null hypothesis of weak identification can be rejected. The results in Table 5 are consistent with respect to the effects of the percentage of Buddhist entrepreneurs in a region on charitable behaviors and establishing businesses in less-developed regions, as presented in Table 3.

Third, multilevel models may have a relatively small number of regions available in this study. This study also used the regional fixed effects model as a robustness check. To account for this, we controlled for three types of regional effects: the eastern, central, and western regions. The results shown in Appendix 6 also support $\mathrm{H} 1, \mathrm{H} 2$, and $\mathrm{H} 3$.

Fourth, we can rule out the reverse effect between charitable behaviors and social entrepreneurship. No literature finds that entrepreneurs' establishing businesses in less-developed regions are more likely to predict their charitable behaviors; rather, the prior literature has indicated that charitable behaviors can help entrepreneurs gain legitimacy and capture entrepreneurial opportunities, such as establishing businesses in less-developed regions (Liu et al., 2019; Wang \& Qian, 2011). It is also possible that the positive relationship between charitable behaviors and establishing businesses in less-developed regions is driven by a latent or unspecified omitted variable. To eliminate this explanation, we adopted a two-stage model (Heckman, 1979). In Model 1 of Appendix 7 , the dependent variable is charitable behaviors. Model 2 presents the results of Heckman's secondstage estimation using the inverse Mills ratio from the first-stage probit model. The dependent variable is establishing businesses in less-developed regions. As can be seen, the coefficient for charitable behaviors is positive and significant $(\beta=0.023, p<0.01)$, suggesting that, ceteris paribus, charitable behaviors have a significantly positive effect on establishing businesses
Table 2 Multicollinearity test

\begin{tabular}{ll}
\hline & $\begin{array}{l}\text { Main model } \\
\text { EO1 }\end{array}$ \\
& VIF \\
\hline Buddhism & 6.93 \\
GDP growth & 4.50 \\
Law enforcement & 2.21 \\
Government activism & 2.18 \\
Confucianism & 1.10 \\
Mean VIF & 3.38 \\
\hline
\end{tabular}

in less-developed regions. Thus, even after considering endogeneity concerns between the two variables, we continue to find evidence that entrepreneurs' charitable behaviors help them establish businesses in less-developed regions.

Fifth, to ensure robust results, we also tested the effect of the percentage of Buddhist entrepreneurs in a region on charitable behaviors and establishing businesses in less-developed regions by respectively using the percentage of Buddhist entrepreneurs in the 2008 and 2010 nationwide surveys. The results shown in Appendices 8 and 9 support $\mathrm{H} 1, \mathrm{H} 2$, and $\mathrm{H} 3$.

Lastly, in order to separate out the social influence of Buddhism on non-Buddhist entrepreneurs from that on own-effects of Buddhist entrepreneurs, we also added some variables like their attitudes toward philanthropy, with responses measured by five-point Likert scales ranging from 1 (strongly unimportant) to 5 (strongly important), and venues for Buddhist activities measured by the number of key Buddhist temples per 10,000 people in a province. Some studies have suggested that the number of Buddhist temples in a province may influence an entrepreneur's Buddhist beliefs, and Buddhist entrepreneurs express more charitable values very closely related to their attitude toward philanthropy (Iannaccone, 1998; Jiang et al., 2015; Marques, 2012). Even after controlling the elements of Buddhist entrepreneurs, we still find evidence that $\mathrm{H} 1, \mathrm{H} 2$, and $\mathrm{H} 3$ are supported (see Appendix 10).

\section{Discussion and conclusion}

This multilevel study contributes to our understanding of how the regional contexts within a country 
Table 3 The mediating role of charitable behaviors between Buddhism and EO1

\begin{tabular}{|c|c|c|c|c|c|}
\hline & $\begin{array}{l}\text { Model } 1 \\
(\mathrm{DV}=\mathrm{EO} 1)\end{array}$ & $\begin{array}{l}\text { Model } 2 \\
(\mathrm{DV}=\mathrm{EO} 1)\end{array}$ & $\begin{array}{l}\text { Model } 3 \\
(\mathrm{DV}=\mathrm{EO} 1)\end{array}$ & $\begin{array}{l}\text { Model } 4 \\
(\mathrm{DV}=\mathrm{CB})\end{array}$ & $\begin{array}{l}\text { Model } 5 \\
(\mathrm{DV}=\mathrm{EO} 1)\end{array}$ \\
\hline \multicolumn{6}{|l|}{ Level 1 (controls) } \\
\hline Gender & $\begin{array}{l}-0.234^{* * * *} \\
(0.054)\end{array}$ & $\begin{array}{l}-0.227^{\text {**** }} \\
(0.054)\end{array}$ & $\begin{array}{l}-0.219 \\
(0.180)\end{array}$ & $\begin{array}{l}-0.257 \\
(0.193)\end{array}$ & $\begin{array}{l}-0.213^{\text {**** }} \\
(0.018)\end{array}$ \\
\hline Age & $\begin{array}{l}0.017^{* * * *} \\
(0.001)\end{array}$ & $\begin{array}{l}0.017^{* * * *} \\
(0.001)\end{array}$ & $\begin{array}{l}0.015^{* *} \\
(0.007)\end{array}$ & $\begin{array}{l}0.012 \\
(0.009)\end{array}$ & $\begin{array}{l}0.015^{* * *} \\
(0.001)\end{array}$ \\
\hline Human capital & $\begin{array}{l}0.189 \\
(0.168)\end{array}$ & $\begin{array}{l}0.195 \\
(0.170)\end{array}$ & $\begin{array}{l}0.138 \\
(0.118)\end{array}$ & $\begin{array}{l}0.194 \\
(0.140)\end{array}$ & $\begin{array}{l}0.142 \\
(0.201)\end{array}$ \\
\hline Unemployment experience & $\begin{array}{l}0.064 \\
(0.296)\end{array}$ & $\begin{array}{l}0.060 \\
(0.295)\end{array}$ & $\begin{array}{l}0.071 \\
(0.279)\end{array}$ & $\begin{array}{l}-0.148 \\
(0.306)\end{array}$ & $\begin{array}{l}0.069 \\
(0.323)\end{array}$ \\
\hline Rural poverty experience & $\begin{array}{l}0.149 \\
(0.194)\end{array}$ & $\begin{array}{l}0.148 \\
(0.196)\end{array}$ & $\begin{array}{l}0.111 \\
(0.157)\end{array}$ & $\begin{array}{l}0.404^{* * *} \\
(0.197)\end{array}$ & $\begin{array}{l}0.110 \\
(0.218)\end{array}$ \\
\hline Startup location hardship & $\begin{array}{l}0.078 \\
(0.053)\end{array}$ & $\begin{array}{l}0.076 \\
(0.053)\end{array}$ & $\begin{array}{l}0.087 \\
(0.145)\end{array}$ & $\begin{array}{l}0.093 \\
(0.167)\end{array}$ & $\begin{array}{l}0.085^{* * * *} \\
(0.018)\end{array}$ \\
\hline Perceived institutional support & $\begin{array}{l}0.157^{\text {***** }} \\
(0.006)\end{array}$ & $\begin{array}{l}0.158^{* * * *} \\
(0.005)\end{array}$ & $\begin{array}{l}0.123^{* * *} \\
(0.057)\end{array}$ & $\begin{array}{l}0.330^{* * * *} \\
(0.060)\end{array}$ & $\begin{array}{l}0.124^{* * * *} \\
(0.009)\end{array}$ \\
\hline Political connections & $\begin{array}{l}0.867^{\text {**** }} \\
(0.052)\end{array}$ & $\begin{array}{l}0.863^{* * *} \\
(0.054)\end{array}$ & $\begin{array}{l}0.640^{\text {**** }} \\
(0.126)\end{array}$ & $\begin{array}{l}2.365^{* * * *} \\
(0.153)\end{array}$ & $\begin{array}{l}0.638^{* * *} \\
(0.051)\end{array}$ \\
\hline Firm age & $\begin{array}{l}0.163^{* * *} \\
(0.003)\end{array}$ & $\begin{array}{l}0.163^{* * *} \\
(0.003)\end{array}$ & $\begin{array}{l}0.008 \\
(0.088)\end{array}$ & $\begin{array}{l}1.559^{* * * *} \\
(0.097)\end{array}$ & $\begin{array}{l}0.010 \\
(0.013)\end{array}$ \\
\hline Firm size & $\begin{array}{l}0.116^{* * * *} \\
(0.010)\end{array}$ & $\begin{array}{l}0.115^{* * *} \\
(0.010)\end{array}$ & $\begin{array}{l}0.047 \\
(0.046)\end{array}$ & $\begin{array}{l}0.778^{* * * *} \\
(0.057)\end{array}$ & $\begin{array}{l}0.047^{* * *} \\
(0.010)\end{array}$ \\
\hline \multicolumn{6}{|l|}{ Level 2 (controls) } \\
\hline GDP growth & $\begin{array}{l}-0.062 \\
(0.059)\end{array}$ & $\begin{array}{l}-0.022 \\
(0.056)\end{array}$ & $\begin{array}{l}-0.042 \\
(0.099)\end{array}$ & $\begin{array}{l}-0.123 \\
(0.153)\end{array}$ & $\begin{array}{l}-0.013 \\
(0.044)\end{array}$ \\
\hline Law enforcement & $\begin{array}{l}-0.015 \\
(0.014)\end{array}$ & $\begin{array}{l}-0.027^{*} \\
(0.015)\end{array}$ & $\begin{array}{l}-0.020 \\
(0.039)\end{array}$ & $\begin{array}{l}0.027 \\
(0.049)\end{array}$ & $\begin{array}{l}-0.029^{\text {**** }} \\
(0.008)\end{array}$ \\
\hline Government activism & $\begin{array}{l}-0.028 \\
(0.019)\end{array}$ & $\begin{array}{l}-0.041^{\text {*** }} \\
(0.017)\end{array}$ & $\begin{array}{l}-0.029 \\
(0.035)\end{array}$ & $\begin{array}{l}-0.068 \\
(0.045)\end{array}$ & $\begin{array}{l}-0.038^{*} \\
(0.020)\end{array}$ \\
\hline Confucianism & $\begin{array}{l}0.024 \\
(0.043)\end{array}$ & $\begin{array}{l}0.006 \\
(0.044)\end{array}$ & $\begin{array}{l}0.016 \\
(0.041)\end{array}$ & $\begin{array}{l}0.037 \\
(0.078)\end{array}$ & $\begin{array}{l}0.003 \\
(0.048)\end{array}$ \\
\hline \multicolumn{6}{|l|}{ Level 2 (predictors) } \\
\hline Buddhism & & $\begin{array}{l}1.024^{* * * *} \\
(0.083)\end{array}$ & & $\begin{array}{l}3.187^{* *} \\
(1.317)\end{array}$ & $\begin{array}{l}0.741^{* * * *} \\
(0.266)\end{array}$ \\
\hline \multicolumn{6}{|l|}{ Level 1 (mediators) } \\
\hline Charitable behaviors & & & $\begin{array}{l}0.114^{\text {**** }} \\
(0.019)\end{array}$ & & $\begin{array}{l}0.113^{* * *} \\
(0.001)\end{array}$ \\
\hline Constant & $\begin{array}{l}-5.017^{\text {**** }} \\
(0.619)\end{array}$ & $\begin{array}{l}-5.048^{\text {***** }} \\
(0.619)\end{array}$ & $\begin{array}{l}-5.214^{* * *} \\
(0.631)\end{array}$ & $\begin{array}{l}-0.175 \\
(0.797)\end{array}$ & $\begin{array}{l}-5.231^{* * * * *} \\
(0.656)\end{array}$ \\
\hline Residual region-level variance & 0.019 & 0.016 & 0.014 & 0.028 & 0.012 \\
\hline Deviance (-2 log likelihood) & 2,374 & 2,373 & 2,331 & 19,328 & 2,330 \\
\hline Observations & 3,486 & 3,486 & 3,486 & 3,486 & 3,486 \\
\hline
\end{tabular}

Footnotes: 18 industry dummies are included in all estimations but not reported in the table. Standard errors appear in parentheses

${ }^{*} p<0.10$

${ }^{* * *} p<0.05$

${ }^{* * * *} p<0.01$

facilitate entrepreneurs' engagement in social entrepreneurship. We find that the percentage of Buddhist entrepreneurs in a region has a positive effect on charitable behaviors and on establishing businesses in less-developed regions. Moreover, charitable behaviors mediate the relationship between the percentage 
Table 4 Robustness results1: The mediating role of charitable behaviors between Buddhism and EO2

\begin{tabular}{|c|c|c|c|c|c|}
\hline & $\begin{array}{l}\text { Model } 1 \\
(\mathrm{DV}=\mathrm{EO} 2)\end{array}$ & $\begin{array}{l}\text { Model } 2 \\
(\mathrm{DV}=\mathrm{EO} 2)\end{array}$ & $\begin{array}{l}\text { Model } 3 \\
(\mathrm{DV}=\mathrm{EO} 2)\end{array}$ & $\begin{array}{l}\text { Model } 4 \\
(\mathrm{DV}=\mathrm{CB})\end{array}$ & $\begin{array}{l}\text { Model } 5 \\
(\mathrm{DV}=\mathrm{EO} 2)\end{array}$ \\
\hline \multicolumn{6}{|l|}{ Level 1 (controls) } \\
\hline Gender & $\begin{array}{l}-0.274^{* * *} \\
(0.045)\end{array}$ & $\begin{array}{l}-0.272^{* * *} \\
(0.048)\end{array}$ & $\begin{array}{l}-0.251^{* *} \\
(0.123)\end{array}$ & $\begin{array}{l}-0.257 \\
(0.193)\end{array}$ & $\begin{array}{l}-0.250^{* * * *} \\
(0.019)\end{array}$ \\
\hline Age & $\begin{array}{l}0.001^{* * *} \\
(0.000)\end{array}$ & $\begin{array}{l}0.001^{* * *} \\
(0.000)\end{array}$ & $\begin{array}{l}-0.001 \\
(0.005)\end{array}$ & $\begin{array}{l}0.012 \\
(0.009)\end{array}$ & $\begin{array}{l}-0.001 \\
(0.002)\end{array}$ \\
\hline Human capital & $\begin{array}{l}-0.058 \\
(0.052)\end{array}$ & $\begin{array}{l}-0.056 \\
(0.052)\end{array}$ & $\begin{array}{l}-0.109 \\
(0.088)\end{array}$ & $\begin{array}{l}0.194 \\
(0.140)\end{array}$ & $\begin{array}{l}-0.109^{* * *} \\
(0.004)\end{array}$ \\
\hline Unemployment experience & $\begin{array}{l}0.181 \\
(0.277)\end{array}$ & $\begin{array}{l}0.178 \\
(0.276)\end{array}$ & $\begin{array}{l}0.222 \\
(0.193)\end{array}$ & $\begin{array}{l}-0.148 \\
(0.306)\end{array}$ & $\begin{array}{l}0.221 \\
(0.341)\end{array}$ \\
\hline Rural poverty experience & $\begin{array}{l}0.422^{* * *} \\
(0.042)\end{array}$ & $\begin{array}{l}0.421^{* * * *} \\
(0.044)\end{array}$ & $\begin{array}{l}0.376^{* * *} \\
(0.123)\end{array}$ & $\begin{array}{l}0.404^{* *} \\
(0.197)\end{array}$ & $\begin{array}{l}0.375^{* * *} \\
(0.053)\end{array}$ \\
\hline Startup location hardship & $\begin{array}{l}0.253^{\text {**** }} \\
(0.045)\end{array}$ & $\begin{array}{l}0.252^{* * * *} \\
(0.048)\end{array}$ & $\begin{array}{l}0.258^{* *} \\
(0.106)\end{array}$ & $\begin{array}{l}0.093 \\
(0.167)\end{array}$ & $\begin{array}{l}0.257^{* * * *} \\
(0.015)\end{array}$ \\
\hline Perceived institutional support & $\begin{array}{l}0.153^{\text {***** }} \\
(0.012)\end{array}$ & $\begin{array}{l}0.154^{* * *} \\
(0.011)\end{array}$ & $\begin{array}{l}0.110^{\text {**** }} \\
(0.040)\end{array}$ & $\begin{array}{l}0.330^{* * * *} \\
(0.060)\end{array}$ & $\begin{array}{l}0.111^{* * * *} \\
(0.007)\end{array}$ \\
\hline Political connections & $\begin{array}{l}0.912^{\text {**** }} \\
(0.173)\end{array}$ & $\begin{array}{l}0.911^{* * *} \\
(0.174)\end{array}$ & $\begin{array}{l}0.556^{* * *} \\
(0.093)\end{array}$ & $\begin{array}{l}2.365^{* * *} \\
(0.153)\end{array}$ & $\begin{array}{l}0.556^{* * *} \\
(0.162)\end{array}$ \\
\hline Firm age & $\begin{array}{l}0.574^{* * * *} \\
(0.015)\end{array}$ & $\begin{array}{l}0.574^{* * *} \\
(0.015)\end{array}$ & $\begin{array}{l}0.345^{* * *} \\
(0.065)\end{array}$ & $\begin{array}{l}1.559^{* * *} \\
(0.097)\end{array}$ & $\begin{array}{l}0.345^{* * *} \\
(0.003)\end{array}$ \\
\hline Firm size & $\begin{array}{l}0.282^{\text {**** }} \\
(0.031)\end{array}$ & $\begin{array}{l}0.281^{* * * *} \\
(0.031)\end{array}$ & $\begin{array}{l}0.159^{* * *} \\
(0.036)\end{array}$ & $\begin{array}{l}0.778^{* * *} \\
(0.057)\end{array}$ & $\begin{array}{l}0.159^{* * * *} \\
(0.018)\end{array}$ \\
\hline \multicolumn{6}{|l|}{ Level 2 (controls) } \\
\hline GDP growth & $\begin{array}{l}-0.117^{* * * *} \\
(0.032)\end{array}$ & $\begin{array}{l}-0.079^{*} \\
(0.041)\end{array}$ & $\begin{array}{l}-0.080 \\
(0.145)\end{array}$ & $\begin{array}{l}-0.123 \\
(0.153)\end{array}$ & $\begin{array}{l}-0.058^{* * * *} \\
(0.011)\end{array}$ \\
\hline Law enforcement & $\begin{array}{l}-0.041 \\
(0.073)\end{array}$ & $\begin{array}{l}-0.056 \\
(0.085)\end{array}$ & $\begin{array}{l}-0.062 \\
(0.077)\end{array}$ & $\begin{array}{l}0.027 \\
(0.049)\end{array}$ & $\begin{array}{l}-0.070 \\
(0.081)\end{array}$ \\
\hline Government activism & $\begin{array}{l}0.041 \\
(0.489)\end{array}$ & $\begin{array}{l}0.018 \\
(0.446)\end{array}$ & $\begin{array}{l}0.044 \\
(0.062)\end{array}$ & $\begin{array}{l}-0.068 \\
(0.045)\end{array}$ & $\begin{array}{l}0.031 \\
(0.448)\end{array}$ \\
\hline Confucianism & $\begin{array}{l}0.038 \\
(0.033)\end{array}$ & $\begin{array}{l}0.016 \\
(0.035)\end{array}$ & $\begin{array}{l}0.032 \\
(0.073)\end{array}$ & $\begin{array}{l}0.037 \\
(0.078)\end{array}$ & $\begin{array}{l}0.019 \\
(0.026)\end{array}$ \\
\hline \multicolumn{6}{|l|}{ Level 2 (predictors) } \\
\hline Buddhism & & $\begin{array}{l}1.223^{* * *} \\
(0.414)\end{array}$ & & $\begin{array}{l}3.187^{* *} \\
(1.317)\end{array}$ & $\begin{array}{l}0.691^{* * *} \\
(0.160)\end{array}$ \\
\hline \multicolumn{6}{|l|}{ Level 1 (mediators) } \\
\hline Charitable behaviors & & & $\begin{array}{l}0.188^{\text {**** }} \\
(0.012)\end{array}$ & & $\begin{array}{l}0.188^{* * * *} \\
(0.002)\end{array}$ \\
\hline Constant & $\begin{array}{l}-3.044^{* * * *} \\
(0.610)\end{array}$ & $\begin{array}{l}-3.042^{* * *} \\
(0.696)\end{array}$ & $\begin{array}{l}-3.340^{* * *} \\
(0.926)\end{array}$ & $\begin{array}{l}-0.175 \\
(0.797)\end{array}$ & $\begin{array}{l}-3.340^{* * *} \\
(0.741)\end{array}$ \\
\hline Residual region-level variance & 0.108 & 0.101 & 0.113 & 0.028 & 0.109 \\
\hline Deviance (-2 log likelihood) & 4,014 & 4,013 & 3,723 & 19,328 & 3,723 \\
\hline Observations & 3,486 & 3,486 & 3,486 & 3,486 & 3,486 \\
\hline
\end{tabular}

Footnotes: 18 industry dummies are included in all estimations but not reported in the table. Standard errors appear in parentheses ${ }^{*} p<0.10$

${ }^{* *} p<0.05$

${ }^{* * *} p<0.01$ 
Table 5 Robustness results2: The endogeneity between Buddhism and EO1

\begin{tabular}{|c|c|c|c|c|c|}
\hline & $\begin{array}{l}\text { First stage } \\
\text { Model } 1 \\
(\mathrm{DV}=\text { Buddhism) }\end{array}$ & $\begin{array}{l}\text { Second stage } \\
\text { Model } 2 \\
(\mathrm{DV}=\mathrm{EO} 1)\end{array}$ & $\begin{array}{l}\text { Model } 3 \\
(\mathrm{DV}=\mathrm{EO} 1)\end{array}$ & $\begin{array}{l}\text { Second stage } \\
\text { Model } 4 \\
(\mathrm{DV}=\mathrm{CB})\end{array}$ & $\begin{array}{l}\text { Second stage } \\
\text { Model } 5 \\
(\mathrm{DV}=\mathrm{EO} 1)\end{array}$ \\
\hline \multicolumn{6}{|l|}{ Level 1 (controls) } \\
\hline Gender & $\begin{array}{l}-0.009^{* * *} \\
(0.002)\end{array}$ & $\begin{array}{l}-0.105^{* *} \\
(0.047)\end{array}$ & $\begin{array}{l}-0.219 \\
(0.180)\end{array}$ & $\begin{array}{l}-0.288 \\
(0.212)\end{array}$ & $\begin{array}{l}-0.109^{* * *} \\
(0.041)\end{array}$ \\
\hline Age & $\begin{array}{l}-0.000 \\
(0.000)\end{array}$ & $\begin{array}{l}0.008^{* * *} \\
(0.001)\end{array}$ & $\begin{array}{l}0.015^{\text {** }} \\
(0.007)\end{array}$ & $\begin{array}{l}0.012^{* * * *} \\
(0.001)\end{array}$ & $\begin{array}{l}0.007^{* * *} \\
(0.000)\end{array}$ \\
\hline Human capital & $\begin{array}{l}-0.002^{* * *} \\
(0.000)\end{array}$ & $\begin{array}{l}0.092 \\
(0.078)\end{array}$ & $\begin{array}{l}0.138 \\
(0.118)\end{array}$ & $\begin{array}{l}0.253 \\
(0.302)\end{array}$ & $\begin{array}{l}0.070 \\
(0.083)\end{array}$ \\
\hline Unemployment experience & $\begin{array}{l}0.003 \\
(0.003)\end{array}$ & $\begin{array}{l}0.015 \\
(0.045)\end{array}$ & $\begin{array}{l}0.071 \\
(0.279)\end{array}$ & $\begin{array}{l}-0.204^{* * *} \\
(0.090)\end{array}$ & $\begin{array}{l}0.028 \\
(0.052)\end{array}$ \\
\hline Rural poverty experience & $\begin{array}{l}-0.003 \\
(0.003)\end{array}$ & $\begin{array}{l}0.087 \\
(0.081)\end{array}$ & $\begin{array}{l}0.111 \\
(0.157)\end{array}$ & $\begin{array}{l}0.425^{* * *} \\
(0.098)\end{array}$ & $\begin{array}{l}0.066 \\
(0.083)\end{array}$ \\
\hline Startup location hardship & $\begin{array}{l}0.001^{*} \\
(0.001)\end{array}$ & $\begin{array}{l}0.044 \\
(0.037)\end{array}$ & $\begin{array}{l}0.087 \\
(0.145)\end{array}$ & $\begin{array}{l}0.079 \\
(0.137)\end{array}$ & $\begin{array}{l}0.052 \\
(0.045)\end{array}$ \\
\hline Perceived institutional support & $\begin{array}{l}0.003^{* * *} \\
(0.001)\end{array}$ & $\begin{array}{l}0.079^{* * *} \\
(0.024)\end{array}$ & $\begin{array}{l}0.123^{* *} \\
(0.057)\end{array}$ & $\begin{array}{l}0.363^{* * *} \\
(0.117)\end{array}$ & $\begin{array}{l}0.060^{* * *} \\
(0.019)\end{array}$ \\
\hline Political connections & $\begin{array}{l}0.006^{*} \\
(0.003)\end{array}$ & $\begin{array}{l}0.465^{* * *} \\
(0.054)\end{array}$ & $\begin{array}{l}0.640^{* * *} \\
(0.126)\end{array}$ & $\begin{array}{l}2.444^{* * *} \\
(0.082)\end{array}$ & $\begin{array}{l}0.352^{* * *} \\
(0.066)\end{array}$ \\
\hline Firm age & $\begin{array}{l}-0.001^{* *} \\
(0.001)\end{array}$ & $\begin{array}{l}0.090^{*} \\
(0.047)\end{array}$ & $\begin{array}{l}0.008 \\
(0.088)\end{array}$ & $\begin{array}{l}1.601^{* * *} \\
(0.014)\end{array}$ & $\begin{array}{l}0.012 \\
(0.053)\end{array}$ \\
\hline Firm size & $\begin{array}{l}0.000 \\
(0.001)\end{array}$ & $\begin{array}{l}0.069^{*} \\
(0.040)\end{array}$ & $\begin{array}{l}0.047 \\
(0.046)\end{array}$ & $\begin{array}{l}0.810^{* * * *} \\
(0.033)\end{array}$ & $\begin{array}{l}0.035 \\
(0.045)\end{array}$ \\
\hline \multicolumn{6}{|l|}{ Level 2 (controls) } \\
\hline GDP growth & $\begin{array}{l}-0.021 \\
(0.014)\end{array}$ & $\begin{array}{l}0.014 \\
(0.078)\end{array}$ & $\begin{array}{l}-0.042 \\
(0.099)\end{array}$ & $\begin{array}{l}0.155^{* *} \\
(0.064)\end{array}$ & $\begin{array}{l}0.008 \\
(0.102)\end{array}$ \\
\hline Law enforcement & $\begin{array}{l}0.003 \\
(0.005)\end{array}$ & $\begin{array}{l}-0.010 \\
(0.015)\end{array}$ & $\begin{array}{l}-0.020 \\
(0.039)\end{array}$ & $\begin{array}{l}-0.011 \\
(0.008)\end{array}$ & $\begin{array}{l}-0.012 \\
(0.017)\end{array}$ \\
\hline Government activism & $\begin{array}{l}0.006 \\
(0.021)\end{array}$ & $\begin{array}{l}-0.023 \\
(0.024)\end{array}$ & $\begin{array}{l}-0.029 \\
(0.035)\end{array}$ & $\begin{array}{l}-0.052 \\
(0.061)\end{array}$ & $\begin{array}{l}-0.021 \\
(0.017)\end{array}$ \\
\hline Confucianism & $\begin{array}{l}0.018^{* * * *} \\
(0.007)\end{array}$ & $\begin{array}{l}0.004 \\
(0.022)\end{array}$ & $\begin{array}{l}0.016 \\
(0.041)\end{array}$ & $\begin{array}{l}0.033 \\
(0.045)\end{array}$ & $\begin{array}{l}0.000 \\
(0.024)\end{array}$ \\
\hline \multicolumn{6}{|l|}{ Level 2 (predictors) } \\
\hline $\begin{array}{l}\text { Instrument } \\
\text { Venues for Buddhist activities }\end{array}$ & $\begin{array}{l}0.001^{* * *} \\
(0.000)\end{array}$ & & & & \\
\hline Buddhism & & $\begin{array}{l}0.655^{* * *} \\
(0.088)\end{array}$ & & $\begin{array}{l}2.755^{* * *} \\
(0.313)\end{array}$ & $\begin{array}{l}0.521^{* * *} \\
(0.038)\end{array}$ \\
\hline \multicolumn{6}{|l|}{ Level 1 (mediators) } \\
\hline Charitable behaviors & & & $\begin{array}{l}0.114^{* * *} \\
(0.019)\end{array}$ & & $\begin{array}{l}0.055^{* * *} \\
(0.008)\end{array}$ \\
\hline Constant & $\begin{array}{l}0.059 \\
(0.118)\end{array}$ & $\begin{array}{l}-2.805^{* * *} \\
(0.175)\end{array}$ & $\begin{array}{l}-5.214^{* * *} \\
(0.631)\end{array}$ & $\begin{array}{l}0.155 \\
(0.166)\end{array}$ & $\begin{array}{l}-2.881^{* * * *} \\
(0.261)\end{array}$ \\
\hline Observations & 3,486 & 3,486 & 3,486 & 3,486 & 3,486 \\
\hline
\end{tabular}

Footnotes: 18 industry dummies are included in all estimations but not reported in the table. Standard errors appear in parentheses ${ }^{*} p<0.10$

${ }^{* *} p<0.05$

${ }^{* * * *} p<0.01$ 
of Buddhist entrepreneurs in a region and establishing businesses in less-developed regions. These findings make important contributions to the literature on social entrepreneurship and prosocial activities.

First, this study contributes to the social entrepreneurship literature by providing a theoretical explanation for the effect of the percentage of Buddhist entrepreneurs in a region on subsequent prosocial activities. We argue that the percentage of Buddhist entrepreneurs in a region cultivates a social norm with respect to prosocial activities, and that this then drives entrepreneurs, both Buddhist and non-Buddhist, to adopt similar charitable behaviors. Specifically, three mechanisms (social capital, political connections, and legitimacy) couched within an isomorphic effect help to explain the effect of the percentage of Buddhist entrepreneurs in a region on establishing businesses in less-developed regions.

Second, this study contributes to the prosocial activities literature by conceptualizing charitable behaviors and establishing businesses in lessdeveloped regions as two distinct prosocial activities. While both activities address some similar social goals and missions, they are distinct in terms of long-term versus short-term orientation and in terms of passive versus proactive behaviors. Moreover, we have proposed and empirically shown that charitable behaviors mediate the relationship between the percentage of Buddhist entrepreneurs in a region and the probability of establishing businesses in less-developed regions.

In addition to making theoretical contributions, this study has several practical implications. First, our study shows that, while institutions across nations influence social entrepreneurship, thosesuch as Buddhism, which is regarded as an informal institution-within different regions of a country and their social norms and values deeply influence social entrepreneurship and highlight its social function in transitional economies such as China. Second, compared with commercial entrepreneurs, who focus on profit maximization, social entrepreneurs are more influenced by social values. This implies that stimulating social entrepreneurship relies not only on traditional institutional pressures, such as government support, but also on the unique institutional forces related to prosocial values.

This study also has some limitations, which provide directions for future research. First, we only considered whether entrepreneurs engage in establishing businesses in less-developed regions to indicate their overall social entrepreneurship. Future research might use some global data, such as the 2009 GEM survey or the Panel Study of Entrepreneurial Dynamics II, to explore the relationship between religion and social entrepreneurship across nations. Second, this study did not differentiate between two components of regional Buddhist entrepreneurs: Buddhist entrepreneurs themselves, and social influences on non-Buddhist entrepreneurs. Future studies should investigate the influence of Buddhism on charitable behaviors and establishing businesses in lessdeveloped regions at the individual level. Third, this study has focused on founders of private enterprises, and we have not generalized our findings beyond the Chinese context. Therefore, it is recommended that researchers also investigate how other religious beliefs might influence entrepreneurs' social entrepreneurial behaviors.

Acknowledgements We thank the Editor-in-Chief Zoltan J. Acs, David B. Audretsch, the anonymous reviewers, and Shaker A. Zahra and Yong Li for their helpful comments and suggestions. The usual disclaimers apply.

Funding The authors acknowledge funding from the National Social Science Foundation of China (grant number: 20AGL008), National Natural Science Foundation of China (grant number: 72172056) and the General Project of Philosophy and Social Science Research in Colleges and Universities of Jiangsu Province (grant number: 2020SJA0254).

Code availability The authors declare that code is available by Stata.

Data availability The authors declare that data is transparent.

\section{Declarations}

Conflict of interest The authors declare no competing interests.

Open Access This article is licensed under a Creative Commons Attribution 4.0 International License, which permits use, sharing, adaptation, distribution and reproduction in any medium or format, as long as you give appropriate credit to the original author(s) and the source, provide a link to the Creative Commons licence, and indicate if changes were made. The images or other third party material in this article are included in the article's Creative Commons licence, unless indicated otherwise in a credit line to the material. If material is not included in the article's Creative Commons licence and your intended use is not permitted by statutory regulation or exceeds the permitted use, you will need to obtain permission directly 
from the copyright holder. To view a copy of this licence, visit http://creativecommons.org/licenses/by/4.0/.

\section{References}

Angelidis, J., \& Ibrahim, N. (2004). An exploratory study of the impact of degree of religiousness upon an individual's corporate social responsiveness orientation. Journal of Business Ethics, 51(2), 119-128. https://doi.org/10. 1023/B:BUSI.0000033606.27489.bf

Audretsch, D. B., Bönte, W., \& Tamvada, J. P. (2013). Religion, social class, and entrepreneurial choice. Journal of Business Venturing, 28(6), 774-789. https://doi.org/10. 1016/j.jbusvent.2013.06.002

Ault, J. K. (2016). An institutional perspective on the social outcome of entrepreneurship: Commercial microfinance and inclusive markets. Journal of International Business Studies, 47(8), 951-967. https://doi.org/10.1057/jibs. 2016.18

Austin, J., Stevenson, H., \& Wei-Skillern, J. (2006). Social and commercial entrepreneurship: Same, different, or both? Entrepreneurship Theory and Practice, 30(1), 1-22. https://doi.org/10.1111/j.1540-6520.2006.00107.x

Bai, W., Kao, P., \& Wu, J. (2021). Returnee entrepreneurs and the performance implications of political and business relationships under institutional uncertainty. Journal of Business Research, 128, 245-256. https://doi.org/10. 1016/j.jbusres.2021.02.014

Baron, R. M., \& Kenny, D. A. (1986). The moderator-mediator variable distinction in social psychological research: Conceptual, strategic, and statistical considerations. Journal of Personality and Social Psychology, 51(6), 1173-1182. https://doi.org/10.1037/0022-3514.51.6.1173

Bhatt, B., Qureshi, I., \& Riaz, S. (2019). Social entrepreneurship in non-munificent institutional environments and implications for institutional work: Insights from China. Journal of Business Ethics, 154(3), 605-630. https://doi. org/10.1007/s10551-017-3451-4

Bolino, M. C., \& Grant, A. M. (2016). The bright side of being prosocial at work, and the dark side, too: A review and agenda for research on other-oriented motives, behavior, and impact in organizations. Academy of Management Annals, 10(1), 599-670. https://doi.org/10.5465/19416 520.2016 .1153260

Brief, A. P., \& Motowidlo, S. J. (1986). Prosocial organizational behaviors. Academy of Management Review, 11(4), 710-725. https://doi.org/10.5465/amr.1986.4283909

Brigham, K. H., Lumpkin, G. T., Payne, G. T., \& Zachary, M. A. (2014). Researching long-term orientation: A validation study and recommendations for future research. Family Business Review, 27(1), 72-88. https://doi.org/10. 1177/0894486513508980

Brock, W. A., \& Durlauf, S. N. (2001). Discrete choice with social interactions. The Review of Economic Studies, 68(2), 235-260. https://doi.org/10.1111/1467-937X. 00168

Dacin, M. T., Dacin, P. A., \& Tracey, P. (2011). Social entrepreneurship: A critique and future directions. Organization Science, 22(5), 1203-1213. https://doi.org/10.1287/ orsc. 1100.0620
Dees, J. G. (1998). Enterprising nonprofits. Harvard Business Review, 76, 54-69.

DiMaggio, P. J., \& Powell, W. W. (1983). The iron cage revisited: Institutional isomorphism and collective rationality in organizational fields. American Sociological Review, 48(2), 147-160. https://www.jstor.org/stable/2095101

Dodd, S. D., \& Seaman, P. T. (1998). Religion and enterprise: An introductory exploration. Entrepreneurship Theory and Practice, 23(1), 71-86. https://doi.org/10.1177/10422 5879802300104

$\mathrm{Du}, \mathrm{X}$. (2015). Is corporate philanthropy used as environmental misconduct dressing? Evidence from Chinese familyowned firms. Journal of Business Ethics, 129(2), 341361. https://doi.org/10.1007/s10551-014-2163-2

Du, X., Du, Y., Zeng, Q., Pei, H., \& Chang, Y. (2016). Religious atmosphere, law enforcement, and corporate social responsibility: Evidence from China. Asia Pacific Journal of Management, 33(1), 229-265. https://doi.org/10.1007/ s10490-015-9441-0

$\mathrm{Du}, \mathrm{X}$. (2017). Religious belief, corporate philanthropy, and political involvement of entrepreneurs in Chinese family firms. Journal of Business Ethics, 142(2), 385-406. https://doi.org/10.1007/s10551-015-2705-2

Estrin, S., Mickiewicz, T., \& Stephan, U. (2013). Entrepreneurship, social capital, and institutions: Social and commercial entrepreneurship across nations. Entrepreneurship Theory and Practice, 37(3), 479-504. https://doi.org/10. 1111/etap. 12019

Fan, G., Wang, X. L., \& Zhu, H. P. (2011). NERI index of marketization of China's provinces 2011 report. Economics Science Press. (In Chinese.).

Greenberg, A. (2000). The church and the revitalization of politics and community. Political Science Quarterly, 115(3), 377-394. https://doi.org/10.2307/2658124

Hechavarría, D. M. (2016). The impact of culture on national prevalence rates of social and commercial entrepreneurship. International Entrepreneurship and Management Journal, 12(4), 1025-1052. https://doi.org/10.1007/ s11365-015-0376-1

Heckman, J. J. (1979). Sample selection bias as a specification error. Econometric: Journal of the Econometric Society, 47(1), 153-161. https://doi.org/10.2307/1912352

Henley, A. (2017). Does religion influence entrepreneurial behavior? International Small Business Journal, 35(5), 597-617. https://doi.org/10.1177/0266242616656748

Hilary, G., \& Hui, K. W. (2009). Does religion matter in corporate decision making in America? Journal of Financial Economics, 93(3), 455-473. https://doi.org/10.1016/j.jfine co.2008.10.001

Hoogendoorn, B. (2016). The prevalence and determinants of social entrepreneurship at the macro level. Journal of Small Business Management, 54(S1), 278-296. https:// doi.org/10.1111/jsbm.12301

Hörisch, J., Kollat, J., \& Brieger, S. A. (2017). What influences environmental entrepreneurship? A multilevel analysis of the determinants of entrepreneurs' environmental orientation. Small Business Economics, 48(1), 47-69. https://doi. org/10.1007/s11187-016-9765-2

Iannaccone, L. (1998). Introduction to the economics of religion. Journal of Economic Literature, 36(3), 1465-1495. https://www.jstor.org/stable/2564806 
Ibrahim, N. A., \& Angelidis, J. P. (2005). The long-term performance of small businesses: Are there differences between "Christian-based" companies and their secular counterparts? Journal of Business Ethics, 58(1-3), 187193. https://doi.org/10.1007/s10551-005-1413-8

Jiang, F., Jiang, Z., Kim, K. A., \& Zhang, M. (2015). Familyfirm risk-taking: Does religion matter? Journal of Corporate Finance, 33, 260-278. https://doi.org/10.1016/j.jcorp fin.2015.01.007

Jin, Z., \& Qiu, Y. (2011). Annual report on religions in China. Social Sciences Academic Press. (In Chinese.).

Korosec, R. L., \& Berman, E. M. (2006). Municipal support for social entrepreneurship. Public Administration Review, 66(3), 448-462. https://doi.org/10.1111/j.1540-6210. 2006.00601.x

Kriger, M., \& Seng, Y. (2005). Leadership with inner meaning: A contingency theory of leadership based on the worldviews of five religions. The Leadership Quarterly, 16(5), 771-806. https://doi.org/10.1016/j.leaqua.2005.07.007

Lepoutre, J., Justo, R., Terjesen, S., \& Bosma, N. (2013). Designing a global standardized methodology for measuring social entrepreneurship activity: The global entrepreneurship monitor social entrepreneurship study. Small Business Economics, 40(3), 693-714. https://doi.org/10. 1007/s11187-011-9398-4

Lim, L. (2010). Chinese turn to religion to fill a spiritual vacuum. National Public Radio, 18. Available at: http://www. npr.org/templates/story/story.php?storyId=128544048. Accessed 7 Nov 2013.

Ling, H. (2004). Buddhism in China. Chinese Intercontinental Press.

Liu, Z., Xu, Z., Zhou, Z., \& Li, Y. (2019). Buddhist entrepreneurs and new venture performance: The mediating role of entrepreneurial risk-taking. Small Business Economics, 52(3), 713-727. https://doi.org/10.1007/ s11187-017-9981-4

Marques, J. (2012). Consciousness at work: A review of some important values, discussed from a Buddhist Perspective. Journal of Business Ethics, 105(1), 27-40. https://doi.org/ 10.1007/s10551-011-0932-8

Marquis, C., Glynn, M. A., \& Davis, G. F. (2007). Community isomorphism and corporate social action. Academy of Management Review, 32(3), 925-945. https://doi.org/10. 5465/amr.2007.25275683

Muñoz, P., \& Kibler, E. (2016). Institutional complexity and social entrepreneurship: A fuzzy-set approach. Journal of Business Research, 69(4), 1314-1318. https://doi.org/10. 1016/j.jbusres.2015.10.098

Neubert, M. J., Bradley, S. W., Ardianti, R., \& Simiyu, E. M. (2017). The role of spiritual capital in innovation and performance: Evidence from developing economies. Entrepreneurship Theory and Practice, 41(4), 621-640. https:// doi.org/10.1111/etp.12172

Nissan, E., Castaño, M. S., \& Carrasco, I. (2012). Drivers of non-profit activity: A cross-country analysis. Small Business Economics, 38(3), 303-320. https://doi.org/10.1007/ s11187-010-9276-5

North, D. C. (1991). Institutions. Journal of Economic Perspectives, 5(1), 97-112. https://doi.org/10.1257/jep.5.1.97

North, D. C. (2005). Understanding the process of economic change. Princeton University Press.
Pace, S. (2013). Does religion affect the materialism of consumers? An empirical investigation of Buddhist ethics and the resistance of the self. Journal of Business Ethics, 112(1), 25-46. https://doi.org/10.1007/ s10551-012-1228-3

Parboteeah, K. P., Walter, S. G., \& Block, J. H. (2015). When does Christian religion matter for entrepreneurial activity? The contingent effect of a country's investments into knowledge. Journal of Business Ethics, 130(2), 447-465. https://doi.org/10.1007/s10551-014-2239-z

Pathak, S., \& Muralidharan, E. (2016). Informal institutions and their comparative influences on social and commercial entrepreneurship: The role of in-group collectivism and interpersonal trust. Journal of Small Business Management, 54(S1), 168-188. https://doi.org/10.1111/jsbm. 12289

Peterson, M. F., Arregle, J. L., \& Martin, X. (2012). Multilevel models in international business research. Journal of International Business Studies, 43(5), 451-457. https:// doi.org/10.1057/jibs.2011.59

Portes, A., \& Sensenbrenner, J. (1993). Embeddedness and immigration: Notes on the social determinants of economic action. American Journal of Sociology, 98(6), 1320-1350. http://www.jstor.org/stable/2781823

Scott, W. R. (1995). Institutions and organizations. Sage.

Scott, W. R. 2005. Institutional theory: Contributing to a theoretical research program. In K. G. Smith, \& M. A. Hitt (Eds), Great minds in management: The process of theory development. Oxford: Oxford University Press.

Semadeni, M., Withers, M. C., \& Trevis Certo, S. (2014). The perils of endogeneity and instrumental variables in strategy research: Understanding through simulations. Strategic Management Journal, 35(7), 1070-1079. https://doi. org/10.1002/smj.2136

Shane, S., \& Cable, D. (2002). Network ties, reputation, and the financing of new ventures. Management Science, 48(3), 364-381. https://doi.org/10.1287/mnsc.48.3.364. 7731

Short, J. C., Moss, T. W., \& Lumpkin, G. T. (2009). Research in social entrepreneurship: Past contributions and future opportunities. Strategic Entrepreneurship Journal, 3(2), 161-194. https://doi.org/10.1002/sej.69

Stephan, U., Uhlaner, L. M., \& Stride, C. (2015). Institutions and social entrepreneurship: The role of institutional voids, institutional support, and institutional configurations. Journal of International Business Studies, 46(3), 308-331. https://doi.org/10.1057/jibs.2014.38

Su, J., Zhai, Q., \& Karlsson, T. (2017). Beyond red tape and fools: Institutional theory in entrepreneurship research, 1992-2014. Entrepreneurship Theory and Practice, 41(4), 505-531. https://doi.org/10.1111/etp.12218

Topa, G. (2001). Social interactions, local spillovers and unemployment. The Review of Economic Studies, 68(2), 261295. https://doi.org/10.1111/1467-937X.00169

Tracey, P. (2012). Religion and organization: A critical review of current trends and future directions. Academy of Management Annals, 6(1), 87-134. https://doi.org/10.5465/ 19416520.2012.660761

Tsui, A. S., \& Farh, J. L. L. (1997). Where guanxi matters: Relational demography and guanxi in the Chinese context. 
Work and Occupations, 24(1), 56-79. https://doi.org/10. 1177/0730888497024001005

Twenge, J. M., Baumeister, R. F., DeWall, C. N., Ciarocco, N. J., \& Bartels, J. M. (2007). Social exclusion decreases prosocial behavior. Journal of Personality and Social Psychology, 92(1), 56-66. https://doi.org/10.1037/0022-3514. 92.1.56

Urbano, D., Aparicio, S., \& Audretsch, D. (2019). Twenty-five years of research on institutions, entrepreneurship, and economic growth: What has been learned? Small Business Economics, 53(1), 21-49. https://doi.org/10.1007/ s11187-018-0038-0

Valliere, D. (2008). Exploring Buddhist influence on the entrepreneurial decision. International Journal of Entrepreneurial Behavior and Research, 14(3), 172-191. https:// doi.org/10.1108/13552550810874682

Venkataraman, S. (1997). The distinctive domain of entrepreneurship research. In J. Katz (Ed.), Advances in entrepreneurship, firm emergence and growth (Vol. 3, pp. 119138). JAI Press.

Wang, H., \& Qian, C. (2011). Corporate philanthropy and corporate financial performance: The roles of stakeholder response and political access. Academy of Management Journal, 54(6), 1159-1181. https://doi.org/10.5465/amj.2009.0548

Weaver, G. R., \& Agle, B. R. (2002). Religiosity and ethical behavior in organizations: A symbolic interactionist perspective. Academy of Management Review, 27(1), 77-97. https://doi.org/10.5465/amr.2002.5922390

Williamson, O. E. (2000). The new institutional economics: Taking stock, looking ahead. Journal of Economic Literature, 38(3), 595-613. https://doi.org/10.1257/jel.38.3.595

Wooldridge, J. M. (2010). Econometric analysis of cross section and panel data. MIT Press.

Wu, J., \& Si, S. (2018). Poverty reduction through entrepreneurship: Incentives, social networks, and sustainability. Asian Business \& Management, 17(4), 243-259. https:// doi.org/10.1057/s41291-018-0039-5

Wu, J., Si, S., \& Wu, X. (2016). Entrepreneurial finance and innovation: Informal debt as an empirical case. Strategic Entrepreneurship Journal, 10(3), 257-273. https://doi. org/10.1002/sej.1214
Wu, J., Si, S. \& Yan, H. (2020). Reducing poverty through the shared economy: Creating inclusive entrepreneurship around institutional voids in China. Asian Business \& Management, 1-29. https://doi.org/10.1057/ s41291-020-00113-3

Wu, J., Si, S., \& Liu, Z. (2022). Entrepreneurship knowledge: When East meets West. Asian Business \& Management, in-press.

Yang, C. K. (1961). Religion in Chinese society: A study of contemporary social functions of religion and some of their historical factors. University of California Press.

Yiu, D. W., Wan, W. P., Ng, F. W., Chen, X., \& Su, J. (2014). Sentimental drivers of social entrepreneurship: A study of China's Guangcai (glorious) program. Management and Organization Review, 10(1), 55-80. https://doi.org/10. 1111/more. 12043

Zahra, S. A., Gedajlovic, E., Neubaum, D. O., \& Shulman, J. M. (2009). A typology of social entrepreneurs: Motives, search processes and ethical challenges. Journal of Business Venturing, 24(5), 519-532. https://doi.org/10.1016/j. jbusvent.2008.04.007

Zahra, S. A., \& Wright, M. (2011). Entrepreneurship's next act. Academy of Management Perspectives, 25(4), 67-83. https://doi.org/10.5465/amp.2010.0149

Zhao, E. Y., \& Lounsbury, M. (2016). An institutional logics approach to social entrepreneurship: Market logic, religious diversity, and resource acquisition by microfinance organizations. Journal of Business Venturing, 31(6), 643662. https://doi.org/10.1016/j.jbusvent.2016.09.001

Zhao, H., \& Lu, J. (2016). Contingent value of political capital in bank loan acquisition: Evidence from founder-controlled private enterprises in China. Journal of Business Venturing, 31(2), 153-174. https://doi.org/10.1016/j.jbusv ent.2015.12.002

Publisher's note Springer Nature remains neutral with regard to jurisdictional claims in published maps and institutional affiliations. 